\title{
Internacjonalizacja polskich uczelni wyższych
}

\section{Wprowadzenie}

Umiędzynarodowienie jest dla polskich uczelni wyższych jednym z kluczowych wyzwań strategicznych na początku XXI w. Dzieli je bowiem duży dystans zarówno do uczelni europejskich, jak i anglosaskich (por. raporty $\mathrm{OECD}^{1}$ ). Podjęcie wyzwań związanych z internacjonalizacją wymagać będzie stworzenia atrakcyjnych programów edukacyjnych w języku angielskim oraz opracowania konkurencyjnych strategii marketingowych. Strategie te powinny opierać się na silnej orientacji rynkowej oraz na wysokiej jakości płatnych usług edukacyjnych oferowanych w języku angielskim.

\section{Uwarunkowania internacjonalizacji uczelni wyższych}

Internacjonalizacja uczelni wyższych jest „procesem włączania wymiaru międzynarodowego, międzykulturowego oraz globalnego w proces świadczenia usług edukacyjnych na poziomie akademickim"2. Motywy internacjonalizacji są mocno zróżnicowane, gdyż mają wymiar polityczny, ekonomiczny, społeczno-kulturowy oraz akademicki ${ }^{3}$.

1 Higher Education and Regions: Globally Competitive, Locally Engaged, OECD, Paris 2007; Education Policy Analysis: Focus on Higher Education, OECD, Paris 2006.

2 S.-J. Chan, Internationalising higher education sectors: explaining the approaches in four Asian countries, "Journal of Higher Education Policy and Management" 2013, vol. 35, no 3, s. 316; Cyt. za: J. Knight, Updating the definition of internationalization, „International Higher Education” 2003, no 33, s. 2-3.

3 J. Knight, Internationalisation of higher education, [w:] Quality and Internationalisation in Higher Education, ed. Organisation of Economic Cooperation and Development, OECD, Paris 1999, s. 13-28. 
W wielu krajach internacjonalizacja jest ważnym projektem politycznym polityki państwa; sprzyja lepszemu zrozumieniu różnych kultur, służy celom polityki zagranicznej i bezpieczeństwa narodowego oraz stymuluje rozwój gospodarczy. Może być także nowym, ważnym źródłem przychodów dla kraju i jego uczelni wyższych. Dobrze służy rozwojowi uczelni, podnoszeniu jakości kształcenia oraz stymulowaniu innowacyjności ${ }^{4}$. Wszędzie jednak jest ona efektem procesów globalizacji ${ }^{5}$.

Uwarunkowania umiędzynarodowienia można podzielić na wewnętrzne i zewnętrzne. Pierwsze są zależne od samych uczelni i wynikają z ich decyzji strategicznych Drugie natomiast dotyczą niezależnych od nich - zmiennych rynkowych i regulacji rządowych oraz międzynarodowych.

\section{Wewnętrzne uwarunkowania internacjonalizacji}

Myślenie o strategii uczelni wyższej w kontekście rynkowym jest dla wielu polskich uczelni publicznych zupełnie nowym wyzwaniem ${ }^{6}$. Jest ono natomiast standardem dla uczelni anglosaskich ${ }^{7}$ i Unii Europejskiej. W ujęciu neoliberalnym internacjonalizacja ma wymiar czysto ekonomiczny ${ }^{8}$. Ukończenie

4 J. Knight, Internationalization, concepts, complexities and challenges, [w:] International Handbook of Higher Education, ed. J.J.F. Forest, P.G. Altbach, Dordrecht 2007, s. 207-227; M. Tadaki, Ch. Tremewan, Reimagining internationalization in higher education: international consortia as a transformative space?, „Studies in Higher Education" 2013, vol. 38, no 3, s. 369.

5 S.S. Bagley, L.M. Portnoi, Setting the stage: global competition in higher education, „New Directions for Higher Education” 2014, vol. 2014, no 168, s. 5-11.

6 T. Domański, Marketing of higher education - future challenges. Marketing szkót wyższych - wyzwania przyszłości, „Management and Business Administration. Central Europe" 2014, vol. 22, no 4, s. 118-132.

7 J. Currie, R. DeAngelis, H. Boer, J. Huisman, C. Lacotte, Globalizing Practises and University Responses: European and Anglo-American Differences, Praeger, Westport, CT 2003; H. de Wit, Internationalization of Higher Education in the United States of America and Europe: A Historical, Comparative, and Conceptual Analysis, Greenwood Press, Westport 2002; idem, Strategies for Internationalisation of Higher Education: A Comparative Study of Australia, Canada, Europe and the United States of America, EAIE, Amsterdam 1995; Ph. Warwick, Y.J. Moogan, A comparative study of perceptions of internationalization strategies in UK universities, "Journal of Comparative \& International Education” 2013, vol. 43, no 1, s. 102-123.

8 J. Currie, R. DeAngelis, H. Boer, J. Huisman, C. Lacotte, Globalizing Practises..., s. 11. 
uczelni postrzegane jest przez zagranicznych studentów jako element osobistej strategii zwiększania własnej konkurencyjności na globalnym rynku pracy, co wpływa na gotowość do inwestowania w proces kształcenia na uczelniach zagranicznych.

Wśród najważniejszych uwarunkowań wewnętrznych należy wymienić sytuację finansową uczelni wyższych i konieczność poszukiwania nowych źródeł przychodów. Kluczowym wymiarem internacjonalizacji uczelni jest więc rosnąca komercjalizacja i zorientowanie rynkowe ${ }^{9}$. Dotyczy to zarówno uczelni amerykańskich, australijskich, nowozelandzkich, kanadyjskich czy brytyjskich, jaki coraz częściej uczelni europejskich. Ważnym ogniwem tego procesu jest budowanie międzynarodowych sieci partnerskich - sprzyjających różnym formom internacjonalizacji na bazie wzajemnych multilateralnych i bilateralnych kontaktów ${ }^{10}$.

Ograniczenia w finansowaniu centralnym wymagają nowego spojrzenia na rynek edukacyjny. Pogarszająca się sytuacja finansowa uczelni publicznych zmuszać je będzie do dywersyfikacji źródeł przychodów. Opłaty wnoszone przez zagranicznych studentów mogą być dla wielu uczelni ważnym źródłem przychodów11. Przychody z czesnego studentów zagranicznych ułatwiają jednocześnie decentralizację systemu zarządzania uczelnią. Internacjonalizacja zwiększa elastyczność wydziałów w procesie kreowania nowych form kształcenia i wprowadzania innowacji, które służą budowaniu większej otwartości na zmiany i oczekiwania międzynarodowej zbiorowości studentów. Uczelnia otwarta na kontakty zewnętrzne jest jednocześnie gotowa do szybszego przejmowania najlepszych praktyk wypracowanych przez zagranicznych partnerów i konkurentów.

\section{Uwarunkowania zewnętrzne}

W ostatnich latach następuje wyraźny wzrost roli czynników zewnętrznych $\mathrm{w}$ procesie generowania zmian na rynku edukacyjnym. Zmiany te są powiązane z procesami globalizacji, wzrostem mobilności studentów i oczekiwaniami

9 S.E. Goddard, Uncommon ground: Indivisble territory and the politics of legitima$c y$, ,International Organization” 2006, vol. 60, s. 35-59.

$10 \mathrm{U}$. Teichler, The changing debate on internationalization of higher education, „Higher Education” 2004, no 48, s. 5-26.

11 T. Domański, Marketing of Higher Education..., s. 118-132; idem, Marketing edukacyjny w warunkach globalizacji rynku, [w:] Marketing w szkole wyższej. Przemiany $w$ orientacji marketingowej, red. G. Nowaczyk, D. Sobolewski, Poznań 2011, s. 23-30. 
pracodawców w zakresie znajomości przez absolwentów specyfiki rynku międzynarodowego. Internacjonalizacja uczelni wyższych jest także ważnym instrumentem polityki państwa w wymiarze politycznym i ekonomicznym. Uniwersytety - obok swej autonomii - są bowiem także instrumentem określonej polityki edukacyjnej, międzynarodowej czy ekonomicznej służącej interesom swych państwit ${ }^{12}$.

Uwarunkowania kulturowe i społeczne internacjonalizacji ustępują dzisiaj miejsca uwarunkowaniom ekonomicznym. Zagraniczni absolwenci uczelni wyższych stają się nie tylko konsumentami usług edukacyjnych, lecz także katalizatorami wymiany handlowej między swoimi macierzystymi krajami i krajem ich uczelni wyższej. Jest to najbardziej widoczne w internacjonalizacji uczelni wyższych w USA, Australii, Kanadzie czy Nowej Zelandii. Ponadto, opłaty wnoszone za studia przez cudzoziemców są znacznie wyższe od opłat studentów krajowych. Przykładowo, w Nowej Zelandii są one trzykrotnie wyższe ${ }^{13}$. Nowa Zelandia, Australia i Kanada pozycjonują się na globalnym rynku edukacyjnym jako alternatywne miejsca do studiowania w odniesieniu do tradycyjne wybieranych anglojęzycznych uczelni w Stanach Zjednoczonych i Wielkiej Brytanii ${ }^{14}$. Czynnik ekonomiczny jest również bardzo widoczny w procesie internacjonalizacji uczelni europejskich ${ }^{15}$.

Z kolei przykładem prymatu uwarunkowań politycznych są Chiny ${ }^{16}$. W ciągu ostatnich 30 lat dokonało się tam przejście od fazy dostrzegania wagi internacjonalizacji (lata 80.), przez budowanie uczelni na poziomie światowym (lata 90.) do rozwoju międzynarodowej globalnej strategii internacjonalizacji going global - po 2000 r. Międzynarodowa edukacja stała się ważnym instrumentem politycznym promowania Chin oraz ich systemu wartości i kultury. Służy ona

12 H. de Wit, European Association for International Education, Amsterdam 1997, s. 25-36; X. Jiang, A probe into the internationalisation of higher education in the New Zealand Context, „Educational Philosopfy and Theory” 2010, vol. 42, no 8, s. 884.

13 X. Jiang, A probe into the internationalisation..., s. 884.

14 X.P. Jiang, Impacts of Globalisation and the Knowledge Economy upon Higher Education in China and New Zealand: Internationalisation in the making, Guangdong People's Publishing House, Guangzhou 2006.

15 H. de Wit, Strategies for Internationalisation of Higher Education: A Comparative...

16 L. Wang, Going global: the changing strategy of internationalization of education in China, "Journal of Higher Education Policy and Management” 2013, vol. 35, no 3, s. 305-315. 
doskonale ekspansji międzynarodowej tego państwa za pośrednictwem mechanizmów soft power opisanych przez Josepha Neya Jr. ${ }^{17}$, obok przewagi wojskowej oraz ekonomicznej (military and economic power) ${ }^{18}$. Wymiana edukacyjna jest tym samym szczególną inwestycją na przyszłość, której efekty polityczne, ekonomiczne i kulturowe są przesunięte w czasie.

Modele promowania międzynarodowej edukacji są obecnie tworzone także w Japonii (The Japan Foundation) oraz w Korei Południowej (The Korea Foundation). Wszystkie one korzystają z wcześniejszych doświadczeń instytucji zachodnioeuropejskich, takich jak: British Council, Alliance Française czy Goethe-Institut.

\section{Specyfika internacjonalizacji uczelni wyższych w Polsce}

Polski rynek edukacyjny stał się w ciągu ostatnich 20 lat (1995-2015) bardzo konkurencyjny. Liberalna polityka doprowadziła do szybkiego wzrostu liczby prywatnych uczelni i do umasowienia studiów. Po roku 1990 powstało blisko 400 niepublicznych szkół wyższych, z których wiele będzie musiało zniknąć z rynku z uwagi na niż demograficzny. Dla najlepszych uczelni publicznych i prywatnych strategie umiędzynarodowienia będą więc szansą na przetrwanie i dalszy rozwój. Stopień umiędzynarodowienia będzie także wyznacznikiem jakości oferowanych usług i prestiżu uczelni wyższej19.

\section{Uwarunkowania demograficzne - spadek liczby potencjalnych studentów}

Bardzo wyraźny spadek liczby krajowych studentów powinien skłaniać polskie uczelnie wyższe do aktywnej penetracji rynków zagranicznych. Szacuje się, iż przy zachowaniu dotychczasowej polityki w 2025 r. liczba polskich studentów może spaść w porównaniu z 2005 r. (1788 tys.) o 42\%, czyli do poziomu

17 J.S. Jr Nye, The information revolution and American soft power, „Asia Pacific Review" 2002, no 9, s. 60-76; idem, Soft power: The means to success in world politics, New York 2004; idem, Public diplomacy and soft power, „The Annals of the American Academy of Political and Social Science" 2008, no 616, s. 94-109.

18 J.S. Jr Nye, Bound to lead: The changing nature of America power, New York 1990.

19 T. Domański, International Model of Higher Education, „Outsourcing and More” 2012, no 4, s. 88-87; idem, Marketing of Higher Education..., s. 118-132; idem, Marketing edukacyjny..., s. 23-30. 
1034 tys. Wysokie spadki notowane będą także w innych krajach, takich jak: Słowacja (-35\%), Korea (-33\%), Czechy (-21\%), Japonia (-19\%) czy Węgry $(-18 \%)$. Najlepszym remedium na spadki liczby krajowych studentów jest poszukiwanie nowych studentów za granicą.

\section{Polityka państwa wobec internacjonalizacji}

Polityka państwa w zakresie internacjonalizacji opierała się dotychczas głównie na programie UE Erasmus. Brak było i jest ciągle wyrazistej polityki państwa w stosunku do studentów spoza Unii Europejskiej. Można odnieść wrażenie, iż internacjonalizacja uczelni wyższych jest spowalniana polityką imigracyjną i wizową - ograniczającą napływ cudzoziemców. Wydaje się, iż polityka ta powinna być bardziej otwarta na przyszłe korzyści dla polskiej gospodarki wynikające z kształcenia cudzoziemców. Ważnym priorytetem powinna być tutaj dywersyfikacja zbiorowości zagranicznych studentów z krajów o znaczeniu strategicznym dla rozwoju gospodarczego Polski oraz wybranych miast i regionów. Odnosi się bowiem wrażenie, iż działania te nie są często do końca skoordynowane i podporządkowane wyrazistym celom strategicznym (polityka edukacyjna, polityka zagraniczna, polityka gospodarcza, polityki rozwoju regionalnego). Kluczowym wyzwaniem dla Polski pozostanie koordynacja polityki naboru cudzoziemców na uczelnie wyższe z celami ekonomicznymi państwa, w tym zwłaszcza z ewolucją rynku pracy. W kontekście strategii internacjonalizacji uczelni wyższych ogromną rolę mogą i powinny odegrać zasady polityki zagranicznej państwa ${ }^{20}$.

Strategia internacjonalizacji uczelni wyższych jest więc bardzo silnie zależna od uwarunkowań zewnętrznych. Najbardziej otwarta oraz innowacyjna strategia internacjonalizacji uczelni wyższej nie będzie mogła być realizowana przy restrykcyjnej polityce wizowej państwa i jego placówek konsularnych działających na różnych rynkach zagranicznych. Potrzebna jest tutaj koordynacja celów i programów strategicznych. Czynnik ten pokazuje raz jeszcze bardzo silną zależność uczelni od zmiennych zewnętrznych i trudność podejmowania działań zdecentralizowanych. Wskazuje także na konieczność budowania strategii internacjonalizacji we współpracy z kluczowymi partnerami strategicznymi,

20 C. Berry, J. Taylor, Internationalisation in higher education in Latin America: policies and practice in Colombia and Mexico, „Higher Education” 2014, no 67, s. 585-601. 
takimi jak: Ministerstwo Spraw Zagranicznych, Ministerstwo Nauki i Szkolnictwa Wyższego, Ministerstwo Spraw Wewnętrznych, Ministerstwo Pracy i Polityki Społecznej, Ministerstwo Gospodarki czy też przedstawiciele zagranicznych i krajowych władz regionalnych, zainteresowani różnymi formami synergii między biznesem, rozwojem regionalnym oraz edukacją w ramach uczelni wyższych.

\section{Ramowy program rządowy umiędzynarodowienia szkolnictwa wyższego}

Polityka rządu polskiego w zakresie umiędzynarodowienia szkolnictwa wyższego została zarysowana w 2014 r. w Programie umiędzynarodowienia szkolnictwa wyższego ${ }^{21}$. Ministerstwo uznało „umiędzynarodowienie za jedno z najważniejszych wyzwań stojących przed polskim szkolnictwem wyższym” (s. 2). Program ten miał służyć: „podnoszeniu konkurencyjności polskich uczelni na rynku międzynarodowym”, „Zwiększeniu udziału nauki we wzroście gospodarczym kraju” oraz wzmacnianiu pozycji Polski na rynku międzynarodowym jako „centrum rozwoju nauki i kształcenia”.

W ocenie autorów programu słabością polskiego procesu internacjonalizacji była zbyt mała liczba programów nauczania w języku angielskim, niedostatek międzynarodowych porozumień edukacyjnych oraz zagranicznych wykładowców. Brak jest także precyzyjnych strategii umiędzynarodowienia poszczególnych uczelni wyższych wkomponowanych wich strategie rozwoju. Mamy więc do czynienia z podwójnym deficytem orientacji międzynarodowej na poziomie uczelni oraz instytucji centralnych ${ }^{22}$.

Program Ministerstwa Nauki i Szkolnictwa Wyższego przewidywał także finansowe wsparcie dla zmian organizacyjnych na uczelniach. Przewidziano m.in. środki na szkolenia i doradztwo w zakresie transferu dobrych praktyk - wypracowanych na różnych uczelniach w zakresie internacjonalizacji oraz na podnoszenie kompetencji międzykulturowych wśród pracowników administracji (23,7 mln euro na podnoszenie kompetencji zarządczych kadr kierowniczych i administracyjnych uczelni). Podkreślono także konieczność prowadzenia nowoczesnych kampanii marketingowych w Internecie, służących

21 Program umiędzynarodowienia szkolnictwa wyższego, MNiSZW, Warszawa 2014.

22 Por. Diagnoza: ibidem. 
budowaniu pozytywnego wizerunku Polski oraz polskich uczelni jako atrakcyjnego miejsca do studiowania. Wydaje się, iż należy dążyć do większej synergii między budowaniem wizerunku kraju oraz jego uczelni wyższych. W tym celu stworzono kampanię marketingową na portalu www.go-poland.pl pod hasłem "Ready, Study, Go! Poland" - zorientowaną na strategiczne rynki edukacyjne (Państwa Partnerstwa Wschodniego, Chiny, Indie, Wietnam, Indonezja, Brazylia, Turcja, Arabia Saudyjska, Katar). Wykorzystano także są media społecznościowe oraz portal Study in Europe Komisji Europejskiej).

W kontekście zmiany rządu w 2015 r. należy zadać pytanie, w jakim stopniu nowe władze będą realizowały ten program, a w jakim stopniu przyjmą nowe założenia programowe oraz budżetowe do realizacji internacjonalizacji uczelni wyższych. Wydaje się, iż strategie internacjonalizacji uczelni wyższych powinny być priorytetem każdego rządu.

\section{Najnowsze trendy dotyczące migracji studentów zagranicznych do Polski}

W 2016 r. w Polsce studiowało ponad 57 tys. studentów zagranicznych ze 157 krajów. W stosunku do 2015 r. nastąpił przyrost o 10 tys. osób (około $23 \%$ !). Studenci zagraniczni stanowią już ponad $4,1 \%$ wszystkich studentów kształcących się w Polsce, w porównaniu z 0,6\% (!) w 2008 r. Ten zauważalny wzrost umiędzynarodowienia jest zarówno wynikiem spadku ogólnej liczby studentów (efekt niżu demograficznego), jak i napływem studentów zagranicznych z Ukrainy.

W roku akademickim 2015/2016 na polskich uczelniach studiowało łącznie 1405133 studentów, czyli o 64254 mniej niż w roku 2014/2015 (-4,6\%!). Liczba studentów zagranicznych tylko w części kompensuje ten spadek. Do pełnej kompensacji w 2015/2016 r. brakowało jeszcze 11\%.

\section{Dominacja studentów ukraińskich}

Według danych GUS z 2016 r. ${ }^{23}$ w roku akademickim 2015/2016 w Polsce studiowało już 30589 studentów ukraińskich (wzrost w przeciągu roku o 23,5\%!). Wynikało to zarówno z czynników politycznych, jak i z wyraźnego obniżenia

23 B. Siwińska, Już ponad 46 tysięcy studentów zagranicznych $w$ Polsce, http://www. perspektywy.pl/portal/index.php?option=com_content\&view=article\&id=2221: 
dla nich opłat za studia. Polityka solidarnościowa rządu RP z Ukrainą zachęciła polskie uczelnie wyższe do oferowania preferencyjnych opłat za studia dla studentów ukraińskich. W wielu uczelniach obniżono je do poziomu opłat wnoszonych przez polskich studentów. Równocześnie trzeba podkreślić, iż centralny system zachęt nie oznaczał żadnego dodatkowego wsparcia na rzecz uczelni wyższych ze strony ministerstwa. Mieliśmy tutaj dobry przykład oddolnego umiędzynarodowienia uczelni bez wsparcia ze strony władz centralnych.

Obecnie studenci z Ukrainy stanowią wiodącą grupę studentów zagranicznych w Polsce (53\%) i udział ten regularnie rośnie. Wynika to zarówno z działań marketingowych, jak i z bezpośrednich konsekwencji konfliktu zbrojnego na Ukrainie - spowodowanego rosyjską agresją. Konflikt wojenny i związane z nim zagrożenia stymulują młodych Ukraińców do szukania bezpiecznego miejsca do studiowania w Polsce. Równocześnie należy mocno podkreślić bliskość geograficzną, kulturową oraz językową Polski i Ukrainy. Atutem studiów w Polsce jest także ich finansowa dostępność i konkurencyjność cenowa, zwłaszcza na tle zamożnych, rozwiniętych krajów starej UE. Dla studentów ukraińskich Polska jest najbliższym krajem UE. Ponadto należy mocno podkreślić historyczne związki Polski oraz Ukrainy oraz obecność dużej liczby Ukraińców o polskim pochodzeniu, dążących do nawiązania nowych relacji z krajem swych przodków. Niektórzy Autorzy mówią wręcz o „ukrainizacji polskich uczelni" 24 .

Równolegle z dynamicznym wzrostem liczby ukraińskich studentów w Polsce obserwuje się postępujący spadek ich liczby w Niemczech. Wydaje się, iż z uwagi na bliskość kulturową Ukraińcy w większym stopniu mogą być zainteresowani pozostaniem po studiach w Polsce. Proces napływu do Polski studentów z Ukrainy jest uwarunkowany także aktywnością samych uczelni oraz komercyjnych pośredników. Atrakcyjność Polski jako miejsca do studiowania

juz-ponad-46-tysiecy-studentow-zagranicznych-w-polsce\&catid=24\&Itemid=119 (dostęp: 16.12.2016).

24 B. Siwińska, Raport „Studenci zagraniczni w Polsce w 2015 roku”, http://www.studyinpoland.pl/konsorcjum/index.php?option=com_content $\& v i e w=$ article $\& i d=6$ 922\%3Araport-qstudenci-zagraniczni-w-polsce-2015\&catid=220\%3A115-newsletter-2015\&Itemid=20 (dostęp: 16.12.2016); V. Gierko, „Ukrainizacja” polskich uczelni na tle umiędzynarodowienia kształcenia na poziomie wyższym w Polsce, „Annales Universitatis Mariae Curie-Skłodowska” 2015, vol. XL, 2, s. 103-119. 
jest postrzegana zarówno w kategoriach bezpieczeństwa, bliskości kulturowej, dyplomu honorowanego w krajach UE, jak i konkurencyjnej relacji jakości studiów do kosztów kształcenia oraz życia.

W grupie zagranicznych studentów w Polsce, drugie miejsce w 2016 r. zajmowali studenci z Białorusi (4615 osób), a dalej: Norwegowie (1581), Hiszpanie (1407) i Szwedzi (1291). W przypadku Ukraińców i Białorusinów możemy mówić także o dużym znaczeniu bliskości geograficznej, kulturowej i językowej. Dodatkowo w odniesieniu do Białorusinów mamy do czynienia z rolą polskich przodków i tym samym z ich historycznymi związkami z Polską. W odniesieniu do Norwegów i Szwedów duża rolę ogrywają studia medyczne, a napływ Hiszpanów powiązany jest z lepszą sytuacją na polskim rynku pracy.

\section{Internacjonalizacja a polityka wschodnia Polski}

Nie ulega wątpliwości, iż liczba oraz struktura zagranicznych studentów w Polsce są w dużym stopniu rezultatem polityki wschodniej polskiego rządu. Po roku 2000 była ona nastawiona na promowanie przyjazdów na studia, studentów polskiego pochodzenia z krajów dawnego ZSRR. Polityka ta nawiązywała do tradycji kształcenia zagranicznych studentów w języku polskim, co nie wymagało przystosowania oferty programowej do ich oczekiwań. Polityka ta opierała się także na wykorzystaniu więzi kulturowych i językowych, które zostały przerwane w okresie funkcjonowania ZSRR. Strategia ta stwarzała również tej grupie możliwości pozostania w Polsce po zakończeniu studiów ${ }^{25}$. Zastosowane przez polski rząd rozwiązanie prawne i finansowe umożliwia posiadaczom tzw. Karty Polaka otrzymanie polskiego stypendium, a następnie nieodpłatne studiowanie w polskiej uczelni wyższej. Z tego rozwiązania korzysta wielu cudzoziemców polskiego pochodzenia, głównie z terenów Ukrainy, Białorusi, Rosji, Kazachstanu oraz z innych państw byłego ZSRR. Warto jednocześnie zaznaczyć, iż mimo że liczba obcokrajowców polskiego pochodzenia zwiększyła się bardzo wyraźnie w ciągu ostatnich 20 lat z 2454 osób w 1995 r. do 5610 w 2014 r., to ich względny udział w całej zbiorowości zagranicznych

25 V. Gierko, Badania losów absolwentów polskich uczelni wyższych z krajów byłego ZSRR, „Studia Politologica Ucraino-Polona” 2013, s. 400-409. 
studentów w Polsce spadł w tym samym okresie z 47,2 do 15,6\%. Wynika z tego bardzo jednoznaczny wniosek, iż dynamika rozwoju programu stypendialnego adresowanego specjalnie do studentów polskiego pochodzenia była znacznie mniejsza aniżeli dynamika rozwoju internacjonalizacji. Mamy tutaj jednocześnie do czynienia z odchodzeniem od modelu historycznych związków internacjonalizacji z grupą obcokrajowców polskiego pochodzenia na rzecz grupy międzynarodowej bez wcześniejszych powiązań z Polską. Zmiany należy uznać za korzystne w kontekście internacjonalizacji, choć, jak się wydaje, państwo polskie nie do końca wykorzystało zasoby studentów zagranicznych polskiego pochodzenia, którzy mogliby pozostać po studiach w Polsce lub stać się aktywnym ambasadorami kontaktów z Polską za granicą.

Z ekonomicznego punktu widzenia polskie uczelnie powinny obecnie dążyć do struktury, w której będą dominowali studenci spoza UE, których wyższe czesne służyć będzie pozyskiwaniu nowych źródeł przychodów.

\section{Relatywnie niski udział studentów azjatyckich}

W grupie zagranicznych studentów kształcących się w Polsce notuje się bardzo niski udział studentów azjatyckich. W roku akademickim 2015/2016 było ich jedynie 6896, co stanowiło około 12\% wszystkich studentów zagranicznych. W porównaniu ze światowymi trendami - wskazującymi na ich dużą mobilność - jest to bardzo niski wskaźnik. Świadczy to o słabości polskiej polityki internacjonalizacji uczelni wyższych w krajach Azji. O wymianie tej decydują bardziej zdecentralizowane działania poszczególnych uczelni oraz wydziałów aniżeli spójne programy różnych ministerstw (MNiSZW, MSZ, MG i MSW). Skuteczna polityka internacjonalizacji powinna opierać się na wspólnej strategii podmiotów centralnych, samorządów (regionalnych oraz miejskich) i biznesu. Odnosi się wrażenie, iż centralna polityka edukacji wyższej jest ciągle słabo skorelowana z polityką zagraniczną oraz rozwojem gospodarczym, a zwłaszcza pozyskiwaniem inwestorów i partnerów gospodarczych z wiodących rynków wschodzących. Wśród studentów azjatyckich największą grupę stanowią Hindusi - 896 (przyrost o 351 osób, czyli o ponad 64\%), Chińczycy - 846; Tajwańczycy - 505; Wietnamczycy - 234; Malezyjczycy - 182, co stanowi wyraźny dowód na brak wykorzystania potencjału tych krajów. 


\section{Niski udział studentów z Ameryki Południowej oraz Afryki}

Z kolei mała liczba studentów pochodzących z krajów Ameryki Południowej (ogółem 173) - wynika głównie z ograniczeń programów stypendialnych, oferowanych przez ich rządy. Blisko połowę tej grupy stanowią Brazylijczycy (82). Zjawisko to jest także obserwowane w innych krajach. Mobilność studentów latynoamerykańskich jest bowiem zależna od uzyskania stypendium rządowego na studia zagraniczne w konkretnym kraju (efekt porozumień bilateralnych i powiązanych z nimi umów rządowych).

Liczba studentów afrykańskich pozostaje ciągle niewielka (1197 osób w 2016 r.), choć obserwuje się tutaj wyraźny wzrost (przyrost o 478 osób, co oznacza dynamikę 66\%!). Może być to efektem konkretnych działań grup parlamentarnych - nastawionych na stymulowanie współpracy z krajami tego kontynentu - w przeszłości szeroko obecnymi na polskich uczelniach. Wydaje się, iż kraje te mają ogromny potencjał, lecz jego wykorzystanie wymaga również uelastycznienia polityki wizowej dla kandydatów na studia oraz stworzenia ułatwień związanych z pozwoleniem na pobyt i pracę. Dotyczy to zwłaszcza krajów francusko- i anglojęzycznych.

\section{Rosnąca pozycja studentów z Turcji}

Przypadek Turcji zasługuje na szczególną uwagę, gdyż liczba studentów tureckich regularnie rośnie i wykazuje dużą dynamikę. W roku akademickim 2015/2016 w Polsce na studiach płatnych kształciło się 1205 osób. Stymulatorem napływu tureckich studentów do Polski jest także unijny program Erasmus, który jest realizowany z bardzo dużą liczbą tureckich uczelni państwowych oraz prywatnych. Program ten pozwala na dużą wymianę studencką i na dobre poznanie Polski, co staje się często impulsem do późniejszej kontynuacji studiów płatnych w Polsce. Jest to także doskonała okazja do promocji Polski jako atrakcyjnego miejsca do studiowania dla studentów tureckich.

Dodatkowym impulsem jest bliskość Niemiec, gdzie wielu studentów tureckich ma swoje rodziny i przyjaciół i gdzie planuje się przenieść po skończeniu studiów z dyplomem uczelni z kraju UE. Konkurencyjny koszt studiów, w połączeniu z niskimi kosztami utrzymania, premiuje dodatkowo Polskę, zwłaszcza w porównaniu z Niemcami. Dodatkowymi atutami są bardzo dobra, nowoczesna infrastruktura akademicka i wysoki poziom kształcenia. Od strony 
marketingowej trzeba podkreślić aktywność tureckich firm prywatnych zajmujących się rekrutacją kandydatów na studia.

Słabością studentów z Turcji jest często relatywnie niższy poziom ogólnego wykształcenia, słabsze przygotowanie do studiowania oraz niedoskonała znajomość języka angielskiego. Wydaje się, iż studenci tureccy przed podjęciem studiów powinni przejść dodatkowy kurs języka angielskiego lub w trakcie studiów uczestniczyć w dodatkowych zajęciach wyrównawczych. Grupa studentów tureckich stanowi dla polskich uczelni interesujący rynek docelowy, choć wymaga bardzo indywidualnego podejścia.

W Polsce brak jest ciągle spójnej wizji internacjonalizacji szkolnictwa wyższego. Stopień umiędzynarodowienia uczelni polskich jest jednym z najniższych w krajach OECD. Jest on wyraźnie niższy niż w krajach Europy Środkowej - Czechy, Węgry czy Słowacja - oraz w krajach nadbałtyckich - Litwa, Łotwa i Estonia. Wkład zagranicznych studentów w funkcjonowanie polskiej gospodarki szacowany jest rocznie na poziomie $150 \mathrm{mln}$ euro. Jest to bardzo mało na tle międzynarodowego rynku edukacyjnego, gdzie 4,5 mln zagranicznych studentów generuje łącznie 100 mld dolarów przychodów ${ }^{26}$. Najbardziej umiędzynarodowionymi rynkami są: Australia (21,2\%), Wielka Brytania $(16,0 \%)$, Austria $(15,4 \%)$ i Nowa Zelandia $(14,2 \%)$. Niemcy, Belgia, Dania, Szwecja, Holandia oscylują wokół średniej OECD, która wynosi około 8\%. W Polsce najbardziej umiędzynarodowione są uczelnie medyczne, oferujące osobny program studiów w języku angielskim (8,58\% w 2012 r.) oraz uczelnie ekonomiczne $(2,08 \%)$. Wyższy stopień umiędzynarodowienia wykazują także uczelnie niepubliczne, co wynika z ich orientacji rynkowej $(2,07 \%)$.

\section{Podsumowanie - wyzwania na przyszłość}

Strategia internacjonalizacji uczelni wyższej powinna być prowadzona za pomocą jej najbardziej umiędzynarodowionych jednostek organizacyjnych. Powinny one wypracowywać najlepsze praktyki, stymulować wprowadzanie

26 B. Siwińska, Już ponad 46 tysięcy studentów zagranicznych w Polsce, http://www.perspektywy.pl/portal/index.php?option $=$ com_content\&view=article\&id=2221:juz-ponad-46-tysiecy-studentow-zagranicznych-w-polsce\&catid=24\&Itemid=119 (dostęp: 03.01.2017); eadem, Over 57119 international students in Poland, http:// www.studyinpoland.pl/en/index.php/news/43-over-57-119-international-students-in-poland (dostęp: 03.01.2017); eadem, Raport „Studenci zagraniczni w Polsce... 
innowacji oraz zwiększać zdolność dostosowawczą uczelni do wymogów międzynarodowego rynku pracy.

Wymaga to tworzenia unikatowych, interdyscyplinarnych programów anglojęzycznych, na których wykładowcami będą najlepsi pracownicy dydaktyczni. W długim okresie sukces strategii internacjonalizacji uczelni wyższej będzie zależał od wyrazistości jej pozycjonowania międzynarodowego i od zdolności zbudowania silnej międzynarodowej marki Wydziału. Wypracowanie silnej marki międzynarodowej wymaga czasu i konsekwencji w doskonaleniu usług edukacyjnych, dostosowanych do oczekiwań studentów zagranicznych. Jednym z kluczowych wyzwań jest zbudowanie zespołu pracowników dydaktycznych w pełni identyfikujących się z tą strategią i studiami anglojęzycznymi. O międzynarodowym postrzeganiu programu decyduje bowiem zaangażowanie wszystkich pracowników, a nie jedynie lidera projektu.

W warunkach polskich anglojęzyczne programy edukacyjne należy traktować jako produkt pokoleniowy, oparty na młodej - dobrze wykształconej za granicą - kadrze dydaktycznej, otwartej na współpracę z zagranicznymi studentami. Sama znajomość zagranicznych programów i realiów akademickich nie jest tutaj wystarczająca.

Strategicznym rozwiązaniem w celu rozszerzenia zakresu internacjonalizacji jest indywidualizacja podejścia do studenta zagranicznego, co umożliwi doskonalenie wzajemnego systemu komunikowania się. System budowania relacji z zagranicznymi studentami powinien być doskonalony już przed rozpoczęciem studiów, jak i w trakcie oraz po ich zakończeniu (relacje $\mathrm{z}$ absolwentami). Nowe wyzwania są tutaj związane z bardzo silnym zróżnicowaniem kulturowym międzynarodowej grupy studenckiej oraz obiektywnymi różnicami w poziomie wykształcenia. Takie podejście jest novum dla uczelni publicznych, nastawionych generalnie na standaryzację usług edukacyjnych.

Na tle standaryzacji i umasowienia programów studiów, umiędzynarodowienie strategii może i powinno być powiązane z personalizacją podejścia do studenta zagranicznego. Personalizacja - oparta na indywidualnym tutoringu, coachingu czy mentoringu - może być w przyszłości wyróżnikiem polskiego modelu internacjonalizacji w wybranych uczelniach wyższych. Jest to tym ważniejsze, iż byłaby to unikatowa przewaga konkurencyjna, niedostępna przy danej cenie w zachodnich uczelniach publicznych. Uczelnie 
zachodnie mówią co najwyżej o specjalnych programach integracji kulturowej, które mają jednak inny charakter ${ }^{27}$.

Polskie uczelnie wyższe posiadałyby tym samym nie tylko przewagę cenową, lecz również przewagę w zakresie jakości oferowanych usług edukacyjnych. Ważnym wyzwaniem internacjonalizacji pozostanie także budowanie wartości dodanej usługi edukacyjnej na bazie nowego systemu relacji z otoczeniem. Szczególny nacisk należy położyć na relacje z biznesem międzynarodowym oraz z władzami lokalnymi i regionalnymi jako potencjalnymi sojusznikami internacjonalizacji. Opisane wyzwania odnoszą się głównie do coraz bardziej zmiennego otoczenia zewnętrznego, które wymaga od uczelni wyższej ciągłego doskonalenia swych zdolności dostosowawczych do zmian rynkowych. Jest to szczególnie trudne w warunkach uczelni publicznej, gdzie zdolność dostosowawcza oraz zmienność pozostają niestety ciągle w rażącej sprzeczności z wewnętrznymi wartościami akademickimi, jakimi są stałość oraz niechęć wobec zmian otoczenia.

\section{Bibliografia}

Bagley S.S., Portnoi L.M., Setting the stage: global competition in higher education, „New Directions for Higher Education” 2014, vol. 2014, no 168.

Berry C., Taylor J., Internationalisation in higher education in Latin America: policies and practice in Colombia and Mexico, „Higher Education” 2014, no 67.

Chan S.-J., Internationalising higher education sectors: explaining the approaches in four Asian countries, "Journal of Higher Education Policy and Management" 2013, vol. 35, no 3.

Currie J., DeAngelis R., Boer H., Huisman J., Lacotte C., Globalizing Practises and University Responses: European and Anglo-American differences, Praeger, Westport, CT 2003.

Domański T., International model of higher education, „Outsourcing and More" 2012, no 4.

Domański T., Marketing edukacyjny w warunkach globalizacji rynku, [w:] Marketing w szkole wyższej. Przemiany w orientacji marketingowej, red. G. Nowaczyk, D. Sobolewski, Poznań 2011.

27 H. de Wit, Strategies for Internationalisation of Higher Education: A comparative study of Australia, Canada, Europe and the United States of America, EAIE, Amsterdam 1995. 
Domański T., Marketing miasta akademickiego. Rola uczelni wyższych w promocji Łodzi, Łódź 2014.

Domański T., Marketing of Higher Education - Future Challenges. Marketing szkół wyższych - wyzwania przyszłości, „Management and Business Administration. Central Europe” 2014, vol. 22, no 4.

Education Policy Analysis: Focus on Higher Education, OECD, Paris 2006.

Gierko V., Badania losów absolwentów polskich uczelni wyższych z krajów byłego ZSRR, „Studia Politologica Ucraino-Polona” 2013.

Gierko V., „Ukrainizacja” polskich uczelni na tle umiędzynarodowienia kształcenia na poziomie wyższym w Polsce, „Annales Universitatis Mariae Curie-Skłodowska" 2015, vol. XL.

Goddard S.E., Uncommon ground: Indivisble territory and the politics of legitimacy, „International Organization” 2006, no 60.

Higher Education and Regions: Globally Competitive, Locally Engaged, OECD, Paris 2007.

Jiang X., A Probe into the Internationalisation of Higher Education in the New Zealand Context, „Educational Philosopfy and Theory” 2010, vol. 42, no 8. Jiang X.P., Impacts of Globalisation and the Knowledge Economy upon Higher Education in China and New Zealand: Internationalisation in the Making, Guangdong People's Publishing House, Guangzhou 2006.

Knight J., Internationalization, concepts, complexities and challenges. In International handbook of higher education, eds J.J.F. Forest, P.G. Altbach, Dordrecht 2007.

Knight J., Internationalisation of Higher Education, [w:] Quality and Internationalisation in Higher Education, ed. Organisation of Economic Cooperation and Development, OECD, Paris 1999.

Knight J., Updating the definition of internationalization, „International Higher Education" 2003, no 33.

Nye J.S. Jr, Bound to Lead: The Changing Nature of America Power, New York 1990.

Nye J.S. Jr, The information revolution and American soft power, „Asia Pacific Review" 2002, no 9.

Nye J.S. Jr, Public diplomacy and soft power, „The Annals of the American Academy of Political and Social Science" 2008.

Nye J.S. Jr, Soft power: The Means to Success in World Politics, New York 2004. Program umiędzynarodowienia szkolnictwa wyższego, MNiSZW, Warszawa 2014. 
Siwińska B., Już ponad 46 tysięcy studentów zagranicznych w Polsce, http:// www.perspektywy.pl/portal/index.php?option=com_content\&view $=$ article\&id=2221:juz-ponad-46-tysiecy-studentow-zagranicznych-w-pols ce\&catid=24\&Itemid=119 (dostęp: 16.12.2016).

Siwińska B. , Over 57119 international students in Poland, http://www. studyinpoland.pl/en/index.php/news/43-over-57-119-international-students-in-poland (dostęp: 03.01.2017).

Siwińska B., Raport „Studenci zagraniczni w Polsce w 2015 roku”, http:// www.studyinpoland.pl/konsorcjum/index.php?option=com_content $\& v i e w=$ article\&id=6922\%3Araport-qstudenci-zagraniczni-w-polsce-2015\&catid=220\%3A115-newsletter-2015\&Itemid=20 (dostęp: 16.12.2016). Siwińska B., Raport „Studenci zagraniczni w Polsce w 2015 roku”, http:// www.studyinpoland.pl/ konsorcjum/index.php?option=com_content $\& v i e w=$ article $\& i d=6922 \% 3$ Araport-qstudenci-zagraniczni-w-polsce-2015\&catid=220\%3A115-newsletter-2015\&Itemid=20 (dostęp: 03.01.2017).

Tadaki M., Tremewan Ch., Reimagining internationalization in higher education: international consortia as a transformative space?, "Studies in Higher Education" 2013, vol. 38, no 3.

Teichler U., The changing debate on internationalization of higher education, „Higher Education” 2004, no 48.

Wang L., Going global: the changing strategy of internationalization of education in China, „Journal of Higher Education Policy and Management” 2013, vol. 35, no 3.

Warwick Ph., Moogan Y.J., A comparative study of perceptions of internationalization strategies in UK universities, „Journal of Comparative \& International Education" 2013, vol. 43, no 1.

Wit de H., European Association for International Education, Amsterdam 1997.

Wit de H., Internationalization of higher education in the United States of America and Europe: A historical, comparative, and conceptual analysis, Greenwood Press, Westport 2002.

Wit de H., Strategies for Internationalisation of Higher Education: A comparative study of Australia, Canada, Europe and the United States of America, EAIE, Amsterdam 1995. 


\section{Streszczenie}

Celem publikacji jest analiza strategii internacjonalizacji uczelni wyższych z uwzględnieniem doświadczeń wielu krajów. Szeroki wachlarz zagranicznych doświadczeń jest wykorzystywany jako tło do zidentyfikowania warunków internacjonalizacji polskich uczelni publicznych. Przyszłość umiędzynarodowienia opiera się na dalszej komercjalizacji takich programów, które wymagają zindywidualizowanego podejścia do zagranicznych studentów, szerszego zakresu oferowanych im usług edukacyjnych oraz zindywidualizowanego doradztwa przy wyborze przyszłych modeli kariery zawodowej. Model internacjonalizacji przyjęty przez Wydział oparty jest na dywersyfikacji grup studentów oraz budowaniu rozległych relacji z lokalną społecznością biznesu.

Stowa kluczowe: Internacjonalizacja uczelni wyższych, marketing uczelni wyższych, usługi edukacyjne, segment studentów zagranicznych, strategie marketingowe uczelni wyższych, indywidualizacja usług edukacyjnych.

\section{Abstract}

The aim of the publication is to examine internationalisation strategies of higher education institutions in the context of experiences accumulated in many countries. Wide range of foreign experiences is used as a background to identify conditions for internationalisation of Polish public universities.

The future of internationalisation is based on further commercialisation of such programmes, which call for personalised approach to foreign students, an expanded array of educational services offered to them, and individualised counselling in developing future professional career models. Internationalisation model adopted by the Faculty is also based on diversification of students' groups and extensive relationships with local business community.

Keywords: Internationalisation of higher education institutions, higher education marketing, educational services, international students segment, marketing strategies of universities, personalised educational services. 